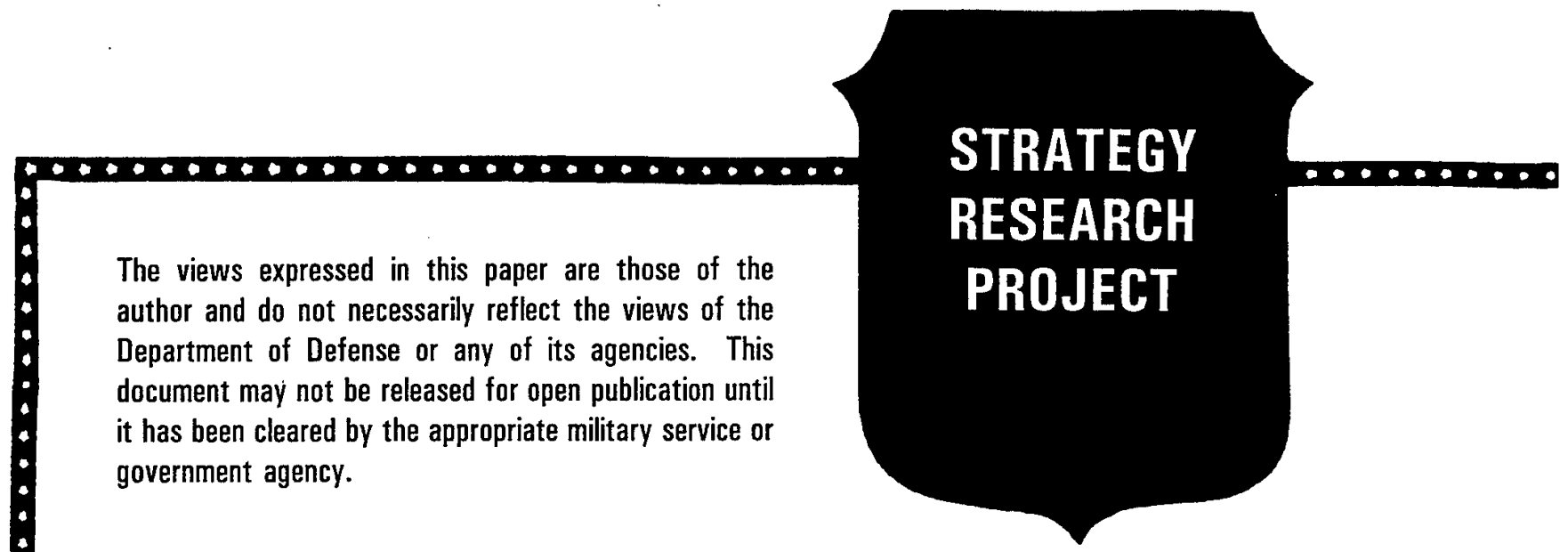

\title{
THE MILITARY AND YOUTH OUTREACH PROGRAMS
}

BY

COLONEL RANDOLPH R. HARRISON

Illinois Army National Guard

DISTRIBUTION STATEMENT A:

Approved for public release.

Distribution is unlimited.

USAWC CLASS OF 1997

U.S. ARMY WAR COLLEGE, CARLISLE BARRACKS, PA 17013-5050

$\star \star \star x *$

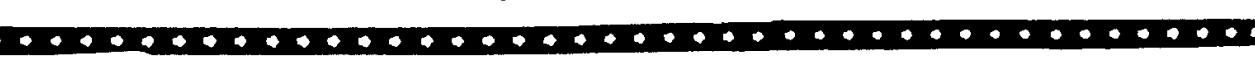


The views in this paper are those of the author and do not necessarily reflect the views of the Department of Defense or any other agencies. This document may not be released for open publication until it has been cleared by the appropriate military service or government agency.

USAWC STRATEGIC RESEARCH PROJECT

THE MILITARY AND YOUTH OUTREACH PROGRAMS

BY

COLONEL RANDOLPH R. HARRISON

ILLINOIS ARMY NATIONAL GUARD

COLONEL BARRY WINGARD

ARMY NATIONAL GUARD

AWC/SRP PROJECT ADVISER

UNITED STATES ARMY WAR COLLEGE

Carlisle Barracks, Pennsylvania 17013

DISTRIBUTION STATEMENT A: Approved for public release.

Distribution is unlimited 
THIS PAGE LEFT INTENTIONALLY BLANK 


\section{ABSTRACT}

AUTHOR: Randolph R. Harrison (Colonel), Illinois Army National Guard

TITLE: The Military and Youth Outreach Programs

FORMAT: Strategic Research Project

DATE: 16 February 1997 PAGES: 29 CLASSIFICATION: Unclassified

The United States National Guard was directed by Congress to test Youth Outreach programs. Congressional intent was to test and evaluate the utilization of the National Guard in providing high school dropouts a way to enter mainstream society and compete as responsible citizens. The program focused on high school dropouts in the 16 to 18 year old range who are drug free, unemployed and not in trouble with the judicial system. The National Guard, utilizing military leadership techniques, physical fitness training, academic instruction and role modeling was tasked. At the center of the program was General Education Degree (GED) training. The goal was to graduate as many students possible with a GED, as well as providing other life coping skills such as conflict resolution, responsible citizenship and financial planning. Upon completing the resident program, students are assigned a mentor, who would provide assistance to the youth. The mentor would provide assistance and would track and report success or failure of the student for a period of a year after graduation from the program. This research paper explores the details of the program, analyzes results and provides recommendations regarding keeping, expanding or eliminating the program. 
THIS PAGE LEFT INTENTIONALLY BLANK 


\section{TABLE OF CONTENTS}

\section{SECTION/SUB- SECTION}

Page(s)

BACKGROUND. $.1-6$

Strategic Relevance of Education......................................................

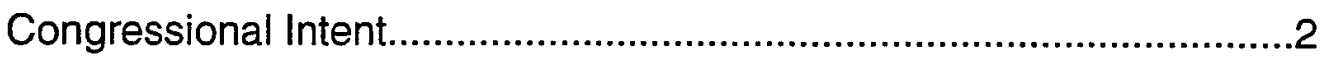

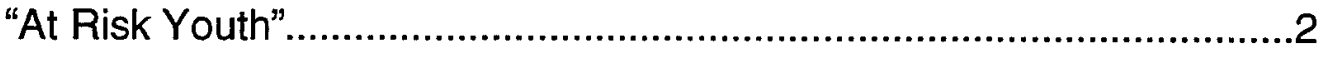

Drugs and Crime

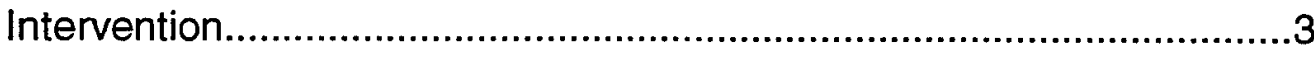

Why The National Guard? ...............................................................

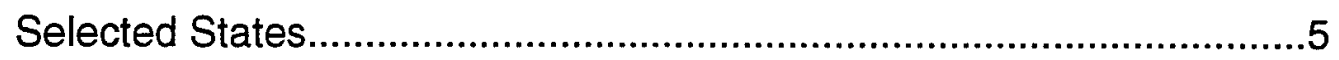

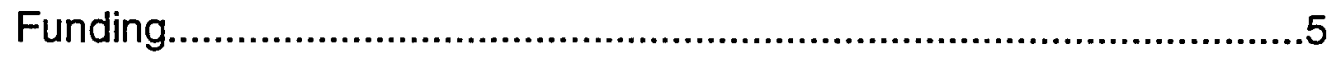

PILOT PROGRAM DEVELOPMENT ...................................................

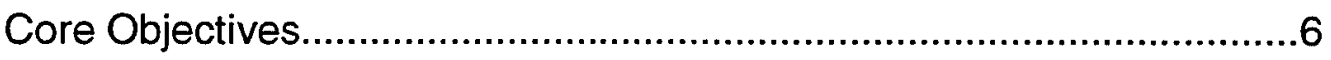

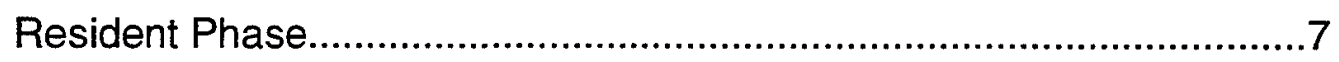

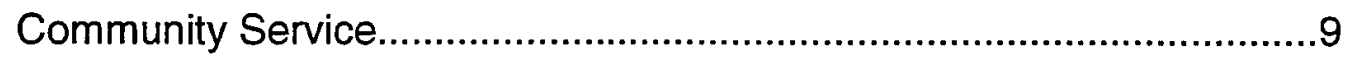

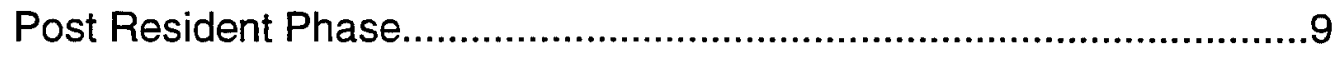

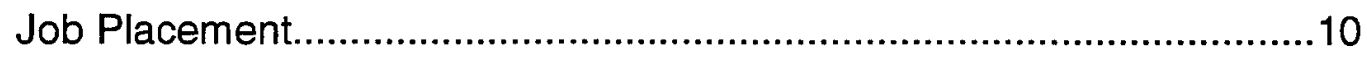

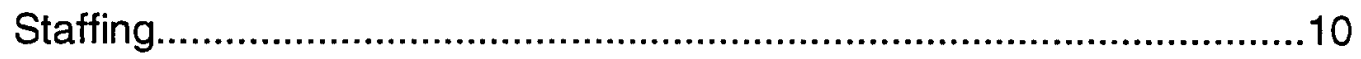

Impact on the Military Mission...........................................................11

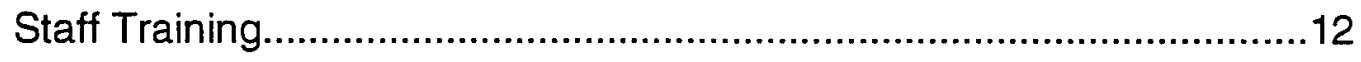

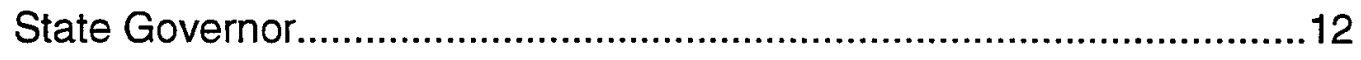

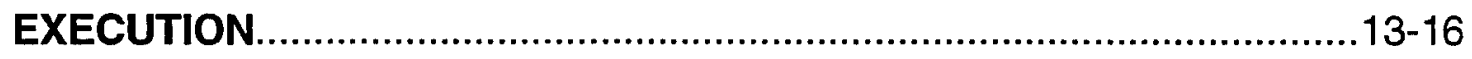

Student Enrollment Goals................................................................13 


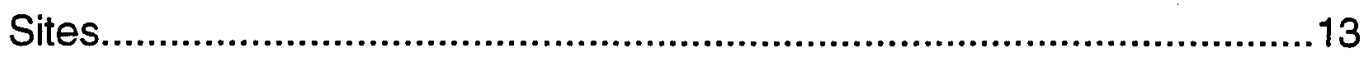

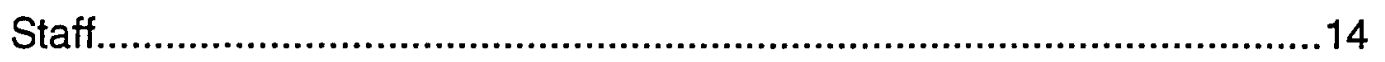

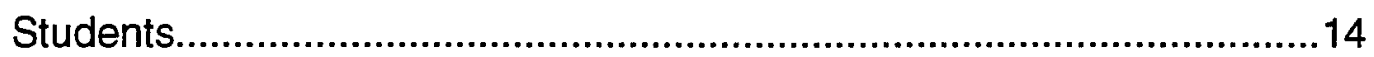

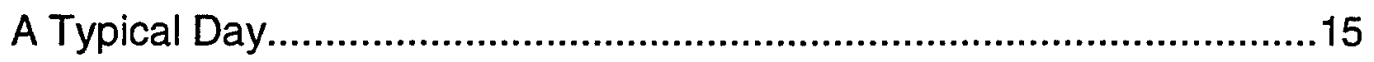

STATISTICAL ANALYSIS OF THE PROGRAM..................................16-19

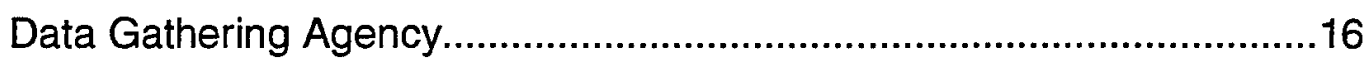

Participant Profile ............................................................................. 17

Education Levels Increases...........................................................17

5000 Most Recent Graduates.............................................................17

Six Cycle Enrollment Vs Graduates Totals.............................................18

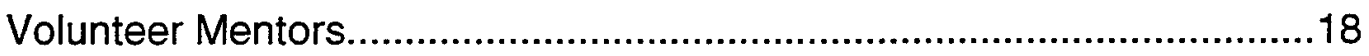

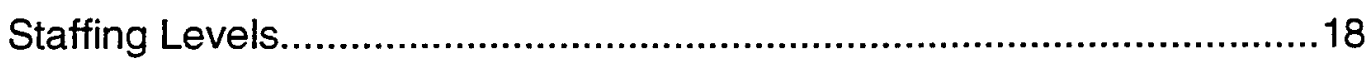

Cost Analysis Average Per Person .........................................................19

ECONOMIC AND SOCIAL PERSPECTIVES .........................................19-21

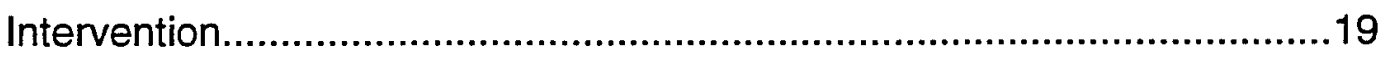

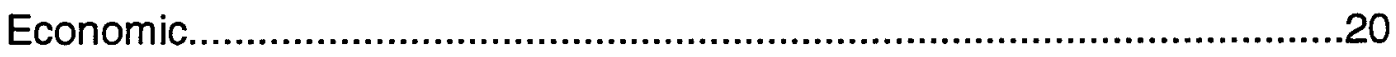

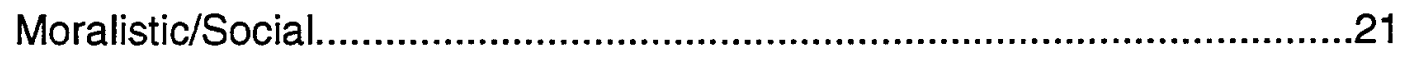

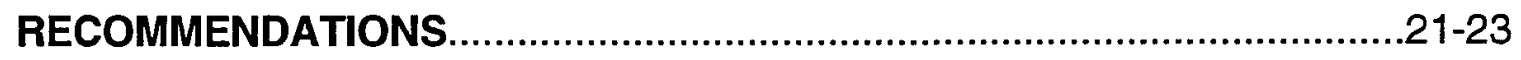

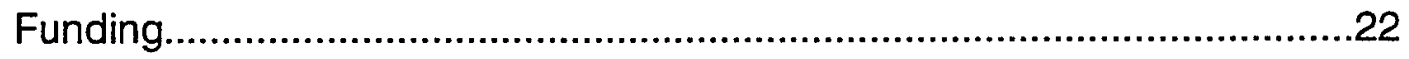

Other Reserve Components....................................................................22

Active Components/Department of Defense...........................................23

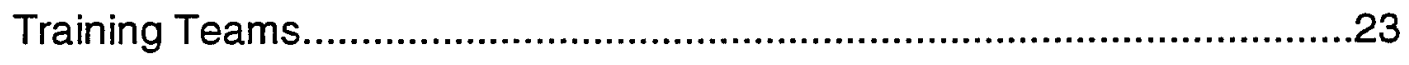

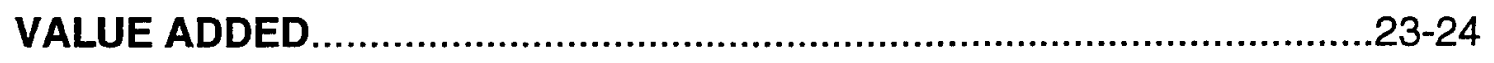


Endnotes...

$.25-26$

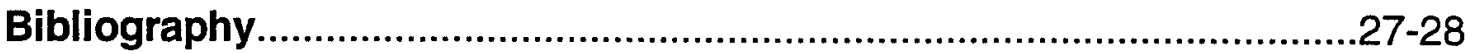

About the Author 


\section{THIS PAGE LEFT INTENTIONALLY BLANK}


In September, 1992, Congress directed the National Guard, through Department of Defense, to implement and test the feasibility of conducting several pilot youth outreach programs. The youth outreach programs were directed to youths who had dropped out of high school. A test period of three years ( $1993-1995)$ was initially authorized. The test period was subsequently extended by Congress through 1997. Congress titled the program "The National Guard Civilian Youth Opportunities Pilot Program".

The program became a part of the Department of Defense "Civil Military Cooperative Action Program" and subsequently a part of the Army's "Domestic Action Program". The purpose of the "Domestic Action Program" is to authorize use of Army human and physical resources in support of development of the American society.

This Strategy Research Paper will examine the largest of the several pilot programs which has been titled "Challenge", to determine if it has been a success or failure and why. The feasibility and affordability of institutionalizing similar programs throughout all States will be examined to include involvement by other Reserve Components. Active Component forces, as well as Department of Defense civilian employees will also be examined for inclusion. The paper will provide recommendations as to feasibility of continuance or expansion of the program.

\section{BACKGROUND}

\section{Strategic Relevance of Education}

From a United States domestic perspective, education of our youth is critical to maintaining the vitality of our current and future economic base. Youth possessing proper education levels will provide our nation with a future work force that can compete in our evolving technological economic environment. Youth who dropout of 
school will be at a distinct disadvantage compared to those who complete their education as both groups compete for jobs.

From a global perspective, the United States must have a competent work force if we are to maintain our global economic superiority.

On February, 4, 1997, President Bill Clinton presented his State of the Union speech to a joint session of congress and the American people. During the President's speech he stated, "Education is a vital national security issue". ${ }^{2}$

\section{Congressional Intent}

The intent of Congress was to determine if youth who have dropped out of attending secondary school (high school) could improve life skills such as life coping, family responsibility, financial, and health skills as well as employment potential. Military based training techniques would be utilized as the core element. The program would also include community service projects. Oversight, supervision and actual conduct of the program would be provided by the National Guard. ${ }^{3}$

\section{At Risk Youth}

"At risk youth" are generally categorized as those youth which are considered the most susceptible to drug or alcohol use, prone to violence, either in the home or living environment and have the greatest potential for confinement. ${ }^{4}$

National statistics in 1993 revealed that over 340,000 American youth dropped out of high school. ${ }^{5}$ These youth tend to use alcohol, drugs, violence and are prone to become part of the welfare or judicial systems. 
School dropouts have bleak prospects for a successful life. Even if employed, high school dropouts do not earn as much as others. As an example, in 1993 the mean monthly income of a non high school graduate (18-24 yrs old) was $\$ 459.00$, compared to a high school graduate at $\$ 783.00$ and a college graduate at $\$ 1,128.00 .^{6}$

\section{Drugs and Crime}

In the United States justice system, on average, $82 \%$ of convicted criminals lack a high school diploma. ${ }^{7}$ The cost of incarceration is extremely high, for example the average annual cost to incarcerate a juvenile is $\$ 39,000.00{ }^{8}$ The cost to taxpayers for long term sentences, for just one convicted criminal, is staggering.

There is extensive information regarding drug use by high school seniors, juvenile arrestees and offenders. In 1991, about 15,700 high school seniors were surveyed. It showed that $44 \%$ of those surveyed students had used drugs. This data, however, generally misses truants and high school dropouts. ${ }^{9}$ It is feasible then to assume that at a minimum, these same statistics could be representative of truants and dropouts, especially in light of $82 \%$ of convicted criminals not having a high school education. According to a National Institute of Justice report, research in the last ten years has revealed strong associations between drug use and crime. ${ }^{10}$

The above data supports a conclusion that use of illegal drugs and commission of crimes are linked to each other. Being a high school dropout probably is also a factor.

\section{Intervention}

Pro-active programs such as Drug Awareness Resistance Education (D.A.R.E.) introduced to youth at an early age, coupled with strong messages from parents 
regarding drugs and staying in school is the best course of action. Continual reenforcement of the above through primary and secondary education levels may have a positive effect on youth. Intervention early with a continual strong anti-drug and crime theme, as well as staying in school, is a logical approach. When this approach fails and some youth drop out of school, other actions must be taken.

There are currently several correctional based youth camps such as New York City's program at Rikkers Island. This program however, is implemented after the youth is incarcerated. ${ }^{11} \mathrm{~A}$ program such as Challenge is designed to intervene before the youth gets into trouble.

\section{Why The National Guard?}

Congress selected the National Guard to administer the Challenge Program for several reasons:

..Working with youth was consistent with the State mission of the National Guard

..Working with youth was consistent with the community role of the National Guard

..Required infrastructure was in place in the National Guard to support programs

..Availability of military skilled trained National Guard personnel ${ }^{12}$

In a speech to the Senate Armed Services Committee, by Senator Sam Nunn, on

Domestic Missions for the Armed Forces, he stated:

"One of the key strengths of the Armed Forces is developing role models. Hardworking, disciplined men and women who command respect and honor in their very presence can serve as a very powerful force among our young people, especially where family structures are weakened by poverty, drugs and crime" ${ }^{13}$ 
He then went on to talk about how our military can assist the nation in Domestic Action Programs, one of which was the recently authorized National Guard youth program. He closed his speech with the following statement:

"By using the capabilities we have in the military, we can assist civilian authorities in addressing the critical fundamentals upon which a healthy society, a healthy economy and a healthy military are built. I believe this is a sensible investment we can make in our future and a vital one. ${ }^{.14}$

\section{Selected States}

Congress did not dictate which States would implement the Challenge Program. The National Guard Bureau contacted the heads of the National Guard, in each State, The Adjutants General and discussed Congressional intent for the implementation of the program. Although many Adjutant Generals showed interest, adequate funding was not available for all to participate. Ten States were initially selected by the National Guard Bureau in 1993 and subsequently expanded to fifteen States in 1994, AL, AZ, AR, GA, HI, IL, LA, MD, MS, NJ, NY, NC, OK, VA, WV. ${ }^{15}$

\section{Funding}

Congress, through the Department of Defense provided funding authorizations to the National Guard Bureau. The authorized funding was to develop the curriculum, hire staff and implement the program for the test years. Funding was increased from year one (1993) for the two following years $(1994,1995)$ due to the growth from ten to fifteen States, who were participating in the program. Because of recent defense wide budget reductions funding authorizations have been reduced each year since 1996. As recent as January, 22, 1997, to assist in funding Reserve Component mobilization insurance, an additional reduction was directed ${ }^{16}$ 
Each funding reduction effects the number of staff personnel in each States program as well as reducing the number of students accepted into the programs.

..FY $93 \$ 44$ Million

..FY $94 \$ 55.9$ Million

..FY $95 \$ 50.2$ Million

..FY $96 \$ 39.2$ Million

..FY $97 \$ 32.8$ Million $(-10 \%)^{17}$

\section{PILOT PROGRAM DEVELOPMENT}

As a pilot program, no basic structure was in place, such as curriculum, scheduling, logistical and administrative support requirements. Congress did however, stipulate basic youth eligibility criteria for entrance into the program. The criteria established was that a youth must be between the ages of 16 and 18, a high school dropout, not in trouble with the law, drug free, unemployed and a volunteer.

In a cooperative effort between the National Guard Bureau and the selected states, they designed the pilot program. States were allowed the latitude to design the curriculum based on unique needs of the particular state. For example, one State may have a need for more anti-gang and conflict resolution skills than another State's program. Core objectives however, and the principles of the program were standard throughout.

\section{Core Objectives}

The Challenge Program consists of a 22 week resident phase and a 12 month postresidential phase. During the resident phase, the student lives in a disciplined quasi- 
military environment 24 hours a day while completing an educational program that focuses on development of the whole person. The resident phase curriculum follows eight core objectives. These objectives are:

1. Academic excellence (including high school level instruction and basic computer literacy)

2. Job skills attainment

3. An increase in physical fitness abilities

4. Leadership/followership

5. Health, sex, nutrition education

6. Exposure and achievement of life coping skills

7. Responsible citizenship

8. Community service ${ }^{18}$

\section{Resident Phase}

The first week of the resident phase concentrates on initial evaluation of the student in the areas of health, current education level, special needs and general in processing into the program.

During this first week, the student is given the nationally recognized Test of Adult Basic Education (TABE). The test provides a benchmark on current education level of the student. Test results are also used in placing the student into the correct academic peer group. With the establishment of a benchmark on education level, it provides an analytical comparison at the end of the resident phase, when the students are again tested. Statistical comparison in this area will be discussed later. 
A key element of the program is to provide the student academic high school level instruction, with the goal of obtaining a General Education Degree (GED). Based on availability of time during the resident phase, not all will earn a GED. Obtaining a GED during the Resident Phase depends on when the youth dropped out of school, first, second, third or fourth year and actual level of education achieved at that time. All students however, participate in the academic portion regardless of level. It is desired that those youth not completing the General Education Degree because of time availability, while in the program, will go on to complete their high school degree after leaving the Challenge Program. Most Challenge Programs have on staff or have access to state certified teachers who provide the classroom instruction to students.

During the first week students are also given a physical examination to determine the health level of the student and to identify any special or limiting physical requirements. Local doctors under contract provide the examinations. Most Challenge Programs have health care specialists on staff to provide for day to day routine medical attention.

During the 22 week resident cycle, students are continually challenged to achieve positive results. For many, it is their first time receiving constructive criticism or praise. Continual interaction between role model Guard instructors and students provides for supervision, coaching, goal setting and feedback on progress. At completion of the demanding 22 week residential phase, students are awarded a Challenge Program graduation diploma, and some also receive a GED certificate. 


\section{Community Service}

Another element of the Challenge Program is to participate in community service. In close co-operation with surrounding communities of the Challenge Program site, students perform community services. This not only promotes harmony between the Challenge Program and community but also teaches students about community involvement. The following are just a few examples provided by Challenge Program Students:

..Sorting food donations for the needy

..Setting up an annual community book sale

..Restoration of playgrounds

..Building repairs at a local $4-\mathrm{H}$ site

..Yard Cleanup for elderly citizens ${ }^{19}$

\section{Post Resident Phase}

During the twelve month post residential phase, the goal is for students to return to their communities, attend post-secondary education, complete high school, or enter the job market. To facilitate tracking students during this phase and to assist the student, a volunteer mentor is provided upon graduation. The mentor could be a Guardsperson, community leader, or an interested community citizen. There is no requirement for the mentor to be in the Guard. The role of the mentor is to provide positive role modeling, to coach and to be an advocate for the youth.

Some mentors who volunteer are already skilled in mentoring through other involvement such as teaching, law enforcement, counseling and coaching. Normally 
these mentors only receive minimal training on mentoring skills. Others that have not been involved in mentoring prior to volunteering receive training from the State's

Challenge Program. The mentor provides feedback to the administering Guard Challenge Program Director as to the youth's progress within the community. Challenge Programs are staffed with an individual(s) whose responsibility is to administer the mentor program. Success after graduation from the resident phase, when the student is no longer in a structured and controlled environment is the final test of the program. Statistics regarding success or failure after graduation will be analyzed later.

\section{Job Placement}

Some Guard Challenge Programs have established cooperative efforts with the business community within their states. Businesses are provided the opportunity to interact with the students for the purpose of future employment. The advantage to the business community is that they are provided a known quantity in a graduating student. A Challenge Program graduate is an individual that has demonstrated positive life skills, is drug free, and is on the way to becoming a responsible citizen.

\section{Staffing}

Staffing of Guard Challenge Programs is accomplished through current Army or Air Guard personnel, retired Army or Air Guard personnel and certified teachers. These personnel are selected based on previous assignment performance, ability to be a positive role model and availability. Personnel staffing Guard Challenge Programs are 
not part of the federal full time support force provided to National Guard units to maintain federal readiness standards.

Challenge Program employees are paid as contractual state employees with federal funds provided to the state. Challenge Program employees receive payment for services from the state and are considered a state employee. They do not however, receive any state or federal benefits because of their contractual status. This is not an unusual arrangement between state and federal governments. As an example, at most National Guard State Headquarters there are state employees who are funded through the state with federal dollars. In some instances other state agencies like Departments of Transportation and Veteran Affairs sometime receive federal funding to hire state employees to administer federally directed programs.

\section{Impact on the Military Mission}

It is important to note that National Guard personnel who are hired as instructors or staff of Challenge Programs are required to perform all weekend drills, annual training periods, special unit training events, schooling, and federally mandated deployments with their units. Hiring of Guardpersons into a Challenge Program does not effect the Federal Mission of their assigned unit. All time devoted to the Challenge Program is in addition to their normal weekend drill or annual training duties and responsibilities associated with being a member of the Guard. A similarity exists between the Challenge Program employee and an employee who works for another state or federal agency and who is also a member of the National Guard, there is no impact on the Guard unit in either instance. 
Funding for Challenge Programs however, does effect the overall Department of Defense budget. Though a small part of the defense budget, it does impact to a degree, especially in an era of reduced budgets. Funding utilized by the Challenge Programs could have been used to fund military personnel or readiness related programs. Alternative funding sources will be discussed later in the recommendation section of this paper.

\section{Staff Training}

Personnel employed as Challenge instructors or staff receive initial training prior to interacting with students. Emphasis is placed on leader skills, counseling techniques, life skill instruction, drug awareness, gang identification, conflict resolution and personal communication skills.

Guardspersons on staff of Challenge Programs bring unique and required skills, learned and practiced within the military. An indirect benefit to the Guardperson is the ability to exercise leadership skills every day they are in contact with students. These learned and practiced skills enhance their capabilities in their military unit of assignment.

\section{State Governor}

In authorizing the National Guard to participate in the pilot youth programs, Congress directed the Department of Defense and the National Guard to enter into an agreement with the Governor of the State. As previously discussed, this agreement provided a vehicle for State Governors to be reimbursed for state civilian personnel cost associated with the program. ${ }^{20}$ 
By directing this cooperative agreement between federal and state government, it provides a sense of ownership of the program with the States Governors. This state partnership allows Governors to provide program leadership through the Guard and more importantly, direct additional state resources to assist with the Challenge Program. An excellent example of this would be the Governor of Illinois, The Honorable Jim Edgar, and the Illinois General Assembly, who have provided state supported college scholarships to selected Illinois Challenge Program graduates. Illinois political leadership has to date appropriated $\$ 450,000$ for scholarships to graduating Challenge Program students. ${ }^{21}$

\section{EXECUTION}

\section{Student Enrollment Goals}

The National Guard Bureau, in coordination with the states, established first cycle goals in regards to initial enrollment of students. Different goals were established based on demographic limitations, fund availability, expected staffing levels and available physical facilities. Goals established ranged from a low of $68(\mathrm{WV})$ and a high

of 300 (IL). The average target goal for the initial participating states was 132 students. 22

\section{Sites}

Upon National Guard Bureau approval of Challenge Program curriculums, states initiated the process of securing sites that provided sleeping quarters, dinning facilities, classrooms and office space. Actual setup of program sites was accomplished, with some states already having adequate facilities available such as Wisconsin at Fort 
Mc Coy and Maryland at Aberdeen Proving Grounds. Other states such as Illinois, had no adequate facilities available, so contracting of sites was accomplished.

\section{Staff}

Advertising positions and selection of staff and instructors were critical elements for overall success. Once selected, an intense staff training program was implemented. A common staff curriculum was utilized to guide training. The staff curriculum emphasized leadership skills, effective communications, conflict resolution, counseling, drug awareness and gang identification. The majority of program staff personnel were hired from available Army and Air National Guardpersons, both active and retired.

\section{Students}

Simultaneous with staff training, logistical and administrative setup, advertising for and selection of first cycle students was underway. Each state started an aggressive program to achieve established student recruitment goals.

Initially, some states were pessimistic about attracting enough students meeting Congressional criteria of being drug free and not in trouble with the law. States canvassed for students by coordinating with local school, community, church officials and political leaders.

Initial concerns of a low response did not materialize. In fact, the actual response from potential students was greater than expected. As an example, the nine states participating in cycle one accepted a total of 1,195 students, from 1,749 applications. Through six cycles, 10,843 have applied with 7, 966 accepted. ${ }^{23}$ Most states currently maintain a waiting list for entrance into upcoming cycles. Limiting factors to acceptance 
of additional students are funding to support additional students, staff, facilities and operating costs.

\section{A Typical Day}

A typical day in a Challenge Program is indeed a challenge to youth, especially those who have dropped out of school and who are not adjusted to the rigors of discipline and a strict regimen. As an example, a typical day for an Illinois Challenge Program student, which is representative of most, looks like this. ${ }^{24}$

5:15 AM - Wake up call

5:15 - 5:45 AM - Personal hygiene

5:45 - 6:30 AM - First formation/physical fitness training

6:30 - 7:35 AM - Personal hygiene

7:35 - 7:55 AM - Breakfast

7:55 - 8:15 AM - Building maintenance

8:15 - 11:45 AM - Computer class

11:45 AM - 12:05 PM - Team leader time (counseling/performance feedback)

12:05 - 12:25 PM - Lunch

12:25 - 1 PM - Team leader time (counseling/performance feedback)

1:00 - 1:05 PM - Formation

1:05 - 4:50 PM - General Education Degree Class

4:50 - 5:35 PM -.Team leader time (normally this is personal time for students)

5:35 - 5:55 PM -.Dinner

6:00 - 8:00 PM - Team leader time(mentoring) 
8:00 - 8:45 PM -.Evening details/personal hygiene

8:45 - 9:15 PM - Study/personal time/lights out

Challenge Program Directors frequently receive feedback from parents regarding changes in youth's behavior. As an example, the following is a letter written to the Director of the Illinois Challenge Program from a mother:

"I am writing to tell you how thankful I am to you, and your staff. My son is a member of Team 7. He came home for the weekend and he has changed so much, it was a pleasure to be with him, and I couldn't say that before. I have tried so hard to teach him the difference between right and wrong and to have respect for other people. I love him so much and it was killing me to see him in trouble all the time. We had a great weekend together and he spoke of you often with much admiration. Please accept my sincere thanks for your wonderful program, you have seemed to have taught my son in 5 short weeks what I have been trying to teach him for 17 long years. I am forever grateful". ${ }^{25}$

\section{STATISTICAL ANALYSIS OF THE PROGRAM}

\section{Data Gathering Agency}

Congress directed that an evaluation of the program be conducted after adequate time was given to implement the program and sufficient data was available. ${ }^{26}$ Congress directed the analysis be conducted by an outside agency. The firm of Social Consultants International, Incorporated, located in Arlington, Virginia was utilized. The firm interacted with the National Guard Bureau and participating states. Data such as enrolled versus graduating, GED attainment rates, gender, ethnic background, etc., was gathered analyzed and reported. 


\section{Participant Profile}

Data reflected that on average throughout all Challenge Programs, that youth participating were predominantly white $54 \%$, African American $32 \%$, Hispanic $9 \%$, Asian American 3\% and Native American at 2\%. This represents a total average in all programs. Some programs, based on regional demographics, had a much different ethnic makeup. As an example the Illinois Challenge Program had $51 \%$ African Americans compared to $33 \%$ whites, which was representative of the large African American population in Illinois. ${ }^{27}$ Nationally, males at age 17 were predominant at $83 \%$ and females at $17 \% .^{28}$

\section{Education Level Increases}

As previously discussed, Challenge Programs used the Test of Adult Basic Education to establish a benchmark of entrance levels of education. The average results on entrance into the program were at the 8.2 grade level for math skills and 8.9 for reading skills. Upon completion of the program students were again tested. They achieved a positive gain from 8.2 to 9.6 in math skills and a positive gain in reading skills from 8.9 to the 10.1 level. $^{29}$

There was a total of 7,966 graduates through six cycles of the program, of those $5,860(74 \%)$ received their GED upon graduation from Challenge. ${ }^{30}$

\section{5,000 Most Recent Graduates}

Intensive tracking of the $\mathbf{5 0 0 0}$ most recent graduates has provided positive statistics. For example, of those youth that have graduated from the Challenge Program, $43 \%$ are currently employed, $22 \%$ have gone on to attend college, $14 \%$ are attending vocational 
schools, $12 \%$ have returned to high school and $9 \%$ are currently serving in the military. ${ }^{31}$

\section{Six Cycle Enrollment VS Graduates Totals}

Of the youth that started the program, a total of $7,966(63 \%)$ graduated. Separation from the program fell into two areas, voluntary and non-voluntary. Students with behavior, substance abuse and insufficient participation problems, 1,903, were involuntarily separated from the program by the Challenge Program Directors . Students with medical problems that limited participation, as well as parents requesting their child's release, were voluntarily separated $1,333 .{ }^{32}$

\section{Volunteer Mentors}

Volunteer mentors $3,500+$, were recruited to work with graduating youth during the post residential phase. Of those recruited 1,855 , some required mentor training from the Challenge mentor trainer. The remainder of the volunteer mentors had prior experience in mentoring, counseling and coaching youth and received minimal training. $^{33}$

\section{Staffing Levels}

A total of 883 staff members were identified and requested to administer the program throughout all pilot programs. The difference of staffing levels correlates to the student target goals of each program. As an example West Virginia requested 35 staff members to administer to a target goal of 90 students, while Illinois requested 147 staff members to administer to 300 students. 
Because of initial funding levels and subsequent budget reductions only 771 staff members in the pilot states were authorized. ${ }^{34}$

\section{Cost Analysis Average Per Person}

By comparing youth who stay in school, youth that are incarcerated and comparable programs involving youth like the Challenge Program, cost factors are as indicated. ${ }^{35}$ ..Boys Town: $\$ 49,868$ per year ..Juvenile Incarceration: $\$ 39,032$ per year ..Group Homes: $\$ 31,000$ per year

..Correctional Boot Camps: $\$ 30,602$ per year ..Job Corps: $\$ 30,602$ per year ..Challenge Programs: $\$ 11,901$ per cycle ..Education: $\$ 5,170$ per school year $. .16-19$ Year Olds Unemployed in US 1994=1.3 Million $^{36}$ ..Mean monthly income non-high school graduate $(18-24)=\$ 459.00^{37}$ .Mean Monthly income high school graduate $(18-24)=\$ 783.00^{38}$

\section{ECONOMIC AND SOCIAL PERSPECTIVES}

\section{Intervention}

After analysis of available data it appears that there is linkage between employment, unemployment, drug use, criminal activity and becoming or not becoming a responsible citizen. Although not a solution in every individuals situation, obtaining an education is a means to a potentially successful life. Intervention to effect staying in school, before the youth's decision to drop out is made, is the desired course of action. Unfortunately, 
it also appears that we will continue to have some youth drop out of school. Programs such as Challenge may provide an answer for some youth at the front end of trouble and can act as another intervention method. Challenge Programs however, should not be considered another path for any youth to gain an education, it is an alternative for troubled youth.

To prevent a youth from dropping out of high school cannot be viewed to be a total local, state or federal government responsibility. Intervention starts in the home with proactive involved parental or relative teams. This coupled with an aggressive education team (teacher, counselor, mentor), presents the obvious solution to stop a youth from dropping out.

When the parent and educator link does not work, then it is incumbent upon governmental entities to become involved and provide a resource for potential success, such as the Challenge Program.

\section{Economic}

From a purely economic perspective, a youth that is potentially headed towards a life of welfare or incarceration, versus being a responsible taxpayer, early intervention is smart in the long term. Comparing a $\$ 39,000$ cost to provide one year of incarceration for a juvenile, to funding a Challenge Program with an average cost per student of $\$ 11,900$ makes sense. Consider a youth that is incarcerated for ten years. This youth will cost taxpayers about $\$ 390,000.00$ and provides no guarantee upon release that the youth will go on to lead a successful life. After weighing all the possibilities of, 
education, incarceration, welfare, responsible citizenship and paying taxes, the conclusion is that that we cannot afford to let this problem exist.

\section{Moralistic/ Social}

From a moralistic and social perspective, do we owe the youth of our country the opportunity to succeed? Is an increased investment in our youth the right thing to maintain our world leadership? Is education a vital strategic interest to the United States both now and into the future? I believe the answers to these questions are yes.

Challenge Programs achieve a cost effective way to influence the outcome for some of our troubled youth. The Challenge Program leads youth into future productivity by using unique military skills, education and mentoring. Before the Challenge Program 7,966 youth faced a bleak future. In just 22 weeks, these youth did something that both their parents and they doubted could be done, they graduated! Witnessing several Challenge Program graduations in Illinois was a moving and an emotional event. In an auditorium filled with parents and friends present, "At Risk Youth", in caps and gowns, receive a diploma from the Governor.

\section{RECOMMENDATIONS}

Based on statistical data, the Challenge Program should be institutionalized in every State. A total of 7,966 youth graduated, with 5,860 attaining their General Education Degree. A significant portion have been employed or are attending higher education institutes.

Although not a complete solution to our nation's dropout problem the military can be leveraged to assist our youth in non-traditional means, such as Challenge! 


\section{Funding}

Funding the Challenge Program utilizing Department of Defense funds is not recommended and should be re-looked by Congress and the President. The limited and increasingly dwindling funds available to Department of Defense should be spent on readiness of forces.

Since federal funding is converted into state funding for Challenge Programs, it would appear that source dollars matters little. Federal funding should be provided by the United States Department of Education. Cooperative funding or sharing from both the state and federal government is also an option. Another area which must be addressed is providing benefits to Challenge Program staff members. This must be done to insure stability in the work force.

What remains a reality however, is that the success of the Challenge Program is based on the unique ability of the military to successfully execute the program. The military must remain engaged.

Using the highest funding authorization in FY 94 of almost $\$ 60$ million, the 15 states involved averaged $\$ 4$ million each to execute the Challenge Program. If the Challenge Program was enlarged to the remaining 39 states and territories, funding would be $\$ 1.5$ billion. A reasonable investment in solving some of this nations youth problems.

\section{Other Reserve Components}

Other Reserve Components offer the same military skills as the National Guard. They should be in a support role to the National Guard. They should provide additional instructors, equipment and in some areas facilities to conduct Challenge programs. 


\section{Active Components/Department of Defense}

Active Component units also have a wealth of unique skills that could be used in assisting youth. We must, however, be extremely careful not to lose sight of the Active Components primary function of defense of our nation.

Utilizing volunteers from Active Component or Department of Defense personnel as post residential Challenge Program mentors could be accomplished without degrading readiness. In addition, there may be opportunities to utilize some Department of Defense facilities that are currently open or scheduled to close. A prime example of this was the Illinois National Guard, with assistance from the General Services Administration, in obtaining a portion of the Chanute Air Force Base in Rantoul, Illinois, for its program.

\section{Training Teams}

The current Challenge Program is the model for expansion. To provide for expansion to all states, short term additional funding should be provided to the National Guard to form mobile training teams from current pilot states. These teams would be utilized in other locations to facilitate a rapid stand up of new Challenge Program sites. The teams could also be used to assist local, state, federal or private organizations to implement similar programs.

\section{VALUE ADDED}

Our nations military is the best in the world. It is imbedded with the highest quality people in our nation. The military brings a unique set of acquired and learned military 
skills, many of which are leadership based. The military adds value to the whole of our country. Although not a complete one package solution to this nations dropout problem, the military can be leveraged, through its Reserve and Active Components, to add more value to the nation and its youth! 
Endnotes

${ }^{1}$ Congressional Conference Report/Authorization; Subtitle I-Youth Service Opportunities; SEC. 1091. National Guard Civilian Youth Opportunity Pilot Program;(a) Program Authority; September 1992

${ }^{2}$ State of the Union speech, President Bill Clinton, February 1997, National television

${ }^{3}$ Congressional Conference Report/Authorization; Subtitle I -Youth Service Opportunities; SEC. 1091. National Guard Civilian Youth Opportunity Pilot Program;(b) Purpose;(c) Conduct of Program in 10 National Guard Jurisdictions; September 1992

${ }^{4}$ National Institute of Justice; Research in Brief; May 1990; 1

${ }^{5}$ Statistical Abstract of the United States, 1995, The National Data Book; 174; No.268

${ }^{6}$ lbid., 158 No.241

${ }^{7}$ Illinois National Guard; Lincoln's Challenge Program Summary, October 1996; A-1

${ }^{8}$ Department of Corrections Yearbook; Juvenile Incarceration

${ }^{9}$ Bureau of Justice Statistics; Drugs, Crime, and the Justice System; 1992; 26

${ }^{10}$ National Institute of Justice; Research in Brief; May 1990; 1

${ }^{11}$ City of New York; High Impact Incarceration Unit Fact Pack

${ }^{12}$ National Guard Bureau Source Book "Challenge"

${ }^{13}$ Strategic Studies Institute US Army War College; Domestic Missions for the Armed Forces; re-published; Speech to Senate Armed Services Committee by Senator Sam Nun, 1992

${ }^{14}$ Ibid.

${ }^{15}$ Ibid.

${ }^{16}$ Memorandum for Challenge Directors; from NGB-PAI-Y, Subject additional $10 \%$ budget reduction

${ }^{17}$ National Guard Bureau Source Book, Challenge 
${ }^{18}$ Ibid.

${ }^{19}$ Illinois National Guard, Lincoln's Challenge Summary Report; October 1996; B-5

${ }^{20}$ Congressional Conference Report/Authorization;Subtitle I-Youth Service Opportunities;Sec. 1091. National Guard Civilian Youth Opportunity Pilot Program;(d) Program Agreements

${ }^{21}$ Illinois National Guard, Lincoln's Challenge Program Summary; October 1996; B-5,6

${ }^{22}$ Social Consultants International, Inc., Statistical Data Report, August 1996; 1

${ }^{23}$ Ibid.. appendix C

${ }^{24}$ Illinois National Guard Lincoln's Challenge schedule

${ }^{25}$ Letter received by Colonel (Ret) Wayne Dunlap, Director of the Illinois Challenge Program from a mother of a student; October 1, 1996

${ }^{26}$ Congressional Conference Report/Authorization; Subtitle I-Youth Service Opportunities; Sec. 1091. National Guard Civilian Youth Opportunity Pilot Program;(k)Report

${ }^{27}$ Illinois National Guard, Lincoln's Challenge Summary Report: October 1996, B-2

${ }^{28}$ Social Consultants International, Inc., Statistical Data Report, August 1996

29 lbid.

${ }^{30}$ lbid.

${ }^{31}$ lbid.

${ }^{32}$ Ibid.

${ }^{33} \underline{\text { lbid. }}$

${ }^{34}$ Ibid.

${ }^{35}$ Ibid.

${ }^{36}$ Statistical Abstract of the United States, The National Data Book, 1995, 420; No. 658

${ }^{37}$ lbid. 158; No. 241 


\section{BIBLIOGRAPHY}

Behring Diagnostics, Inc.Community Anti-Drug Coalitions of America(CACDA)Strategizer; 23. The National Guard in Defense of Americas Children

Bureau of Justice Statistics; A National Report; Drugs, Crime, and the Justice System; 1992

Clinton, William, President of the United States, State of the Union Speech, 4 February 1997

Clinton, William, President of the United States, A National Security Strategy of Engagement and Enlargement. February 1996

Collingswood, Thomas R. Ph.D., Health Promotion. The Use of a Staff Training Model for Implementing Fitness Programming to Prevent Substance Abuse with At-Risk Youth, Volume 9, Number 1, September, October 1994

Congressional Conference Report/Authorization; Section 1091. National Guard Civilian Youth Opportunities, The Pilot Program

Dembo, Richard, Williams, Linda, Wish,Eric,Schmeider,.National Institute of Justice, Research in Brief, May 1990

Dunlap, Wayne, Col (Ret), Director Lincoln's Challenge, Program Summary, October 1996

Dunlap, Wayne, COL (Ret), Director, Lincoln's Challenge, Oral Interviews, September/October 1996

McCaffrey, Barry, Director, Office of National Drug Control Policy, Reducing Drug Use and its Consequences in America; August, 1996

McCaffrey, Barry, Director, Office of National Drug Control Policy.Pulse Check National Trends in Drug Abuse, Spring 1996

McGrath, Linda, Mother to Challenge Student, Letter to COL Wayne Dunlap, Director Lincoln's Challenge, October 1996

National Guard Bureau, National Guard Youth Programs Source Book, undated 
Nunn, Sam US Senator, speech titled Domestic Missions For The Armed Forces; February 1993; printed by the United States Army War College; Fourth Annual Conference on Strategy; Strategy in Periods of Transition

Patrissi, Joseph, Executive Officer High Impact Incarceration Unit, City of New York, Department of Corrections, Correction Options Division, Rikkers Island, New York, Oral Interview, September 1996

Rosenberger, Lief, Ph.D., Americas Drug War Debacle, 1996

Seiver, Vernon, COL (Ret), Director, Maryland Free State Challenge Program, Oral Interview, January 1997

Statistical Abstract of the United States; The National Data Book, 1995

Social Consultants International, Incorporated, Statistical Data Report, August 1996 


\section{ABOUT THE AUTHOR}

Colonel Harrison has over 31 years of military service, 29 of which have been as a full time Illinois Army National Guardsmen. He served as an enlisted man for three years, and was commissioned in July of 1968.

Since commissioning, Colonel Harrison has been a platoon leader in a Nike Hercules (Nuclear) firing Battery; correctional officer and S1 in an Military Police Battalion; Security, Plans, Operations Officer in a Rear Area Operations Center(RAOC); Brigade S3; Training Administrator; Deputy Director of Training for the Illinois National Guard; Battalion Commander; and a Brigade Commander within the Illinois Army National Guard.

Prior to attending the Army War College, Colonel Harrison was the Director of Plans, Operations, Training, Military Support to Civil Authorities for the Illinois Army National Guard.

Colonel Harrison participated in the initial phases of implementing the Challenge program within Illinois. He assisted with the development of the initial training curriculum of the Illinois National Guard, Lincoln's Challenge Program. 